Portland State University

PDXScholar

Spring 9-1-2017

\title{
The Function of Religion in the Israeli-Palestinian Conflict
}

Stephanie Claire Mitchell

Portland State University

Follow this and additional works at: https://pdxscholar.library.pdx.edu/open_access_etds

Part of the Islamic Studies Commons, Peace and Conflict Studies Commons, and the Political Science Commons

Let us know how access to this document benefits you.

\section{Recommended Citation}

Mitchell, Stephanie Claire, "The Function of Religion in the Israeli-Palestinian Conflict" (2017).

Dissertations and Theses. Paper 3939.

https://doi.org/10.15760/etd.5823

This Thesis is brought to you for free and open access. It has been accepted for inclusion in Dissertations and Theses by an authorized administrator of PDXScholar. Please contact us if we can make this document more accessible: pdxscholar@pdx.edu. 
The Function of Religion in the Israeli-Palestinian Conflict

by

Stephanie Claire Mitchell

A thesis submitted in partial fulfillment of the

Requirements for the degree of

\author{
Master of Science \\ in \\ Conflict Resolution
}

Thesis Committee:

Harry Anastasiou, Chair

Robert Gould

Barbara Tint

Portland State University

2017 
(C) 2017 Stephanie Claire Mitchell 


\begin{abstract}
The role of religion in politics has been rising to the forefront of history in the Middle East for a number of decades and more so since $9 / 11$, raising significant questions as to whether religion functions as a catalyst for conflict or peace. This thesis focuses specifically on the role of religion in the Israeli-Palestinian conflict and the manner in which actors incorporate religion into their national politics. In doing so, the inquiry focuses on the proponents of religion on both the Jewish and the Palestinian sides in addressing a) territorial rights, b) interpretations in the use of deadly force and violence, and c) interpretations of the final political goal to be attained. In the context of the broader nationalism of each side, the study reflects on different approaches to religion and how they may provide perspectives that are either catalytic to conflict or catalytic to building peace. In this light, the inquiry of this thesis analyzes and contrasts religious nationalism and pro-peace religiosity, concluding with implications and directives for conflict resolution.
\end{abstract}




\section{Table of Contents}

Abstract.......................................................................................i

Chapter 1: Introduction...............................................................1

1.1 Deciding on the Topic......................................................

1.2 Problem Statement.......................................................... 3

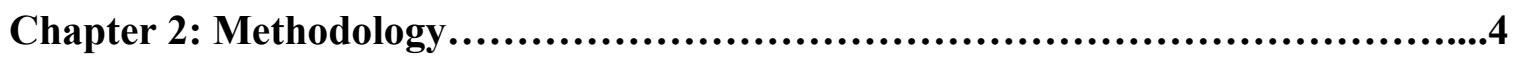

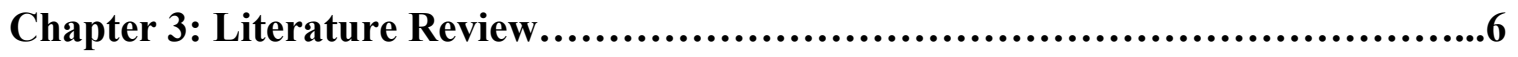

Chapter 4: Analysis................................................................13

4.1 Religious Migration and Rising Trends .................................. 13

4.2 The Role of Religion on the Palestinian side: Profile of Hamas' Ideology....17

4.2.1 The Role of Religion in Determining Territorial Rights ..................18

4.2.2 Religious Interpretations in the Use of Deadly Force and Violence.....19

4.2.3 Religious Interpretation of the Final Political Goal......................22

4.3 The Role of Religion on the Israeli Side: Profile of Religious Zionist Ideology ...24

4.3.1 The Role of Religion in Determining Territorial Rights ..................25

4.3.2 Religious Interpretations in the Use of Deadly Force and Violence......28

4.3.3 Religious Interpretation of the Final Political Goal ........................31

4.3.4 How Religious Nationalists Saw Donald Trump ...........................33

Chapter 5: Comparative Contrast in the Functions of Religion on the Respective

Sides.....................................................................................35

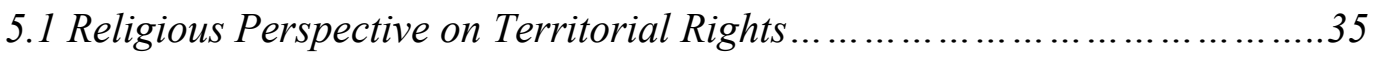


5.3 Religious Perspective on the Final Political Goal.....................................

Chapter 6: Alternative Approaches to the Role of Religion-Peace......................38

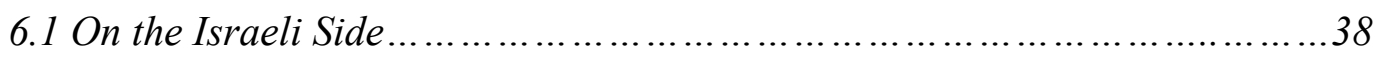

6.2 On the Palestinian Side ..................................................41

6.3 How do They Define Religion Differently.................................43

6.4 Abrahamic Religions...................................................... 43

Chapter 7: Concluding Remarks and the Way Forward: Recommended Directives

for Conflict Resolution.........................................................46

References.......................................................................50 


\section{Chapter 1: Introduction}

\subsection{Deciding on the Topic}

The Israeli-Palestinian conflict was my main focus throughout my graduate career. My interest in the conflict started after my first journey to the Holy Land in a program that was gifted as a birth right to people born of Jewish heritage. When I was there, I immediately I felt that I was expected to take a side in the Israeli-Palestinian conflict. I was filled with nothing short of blistering emotion, resulting in a crisis of identity. I was drawn by this intrigue so much that the following summer I was lucky enough to find an internship in Jerusalem at a small organization called Interfaith Encounter Association. It facilitates dialogue between Arabs and Jews in the Holy Land. During that time, much of my academic work focused on interethnic dialogue between Jews and Palestinians, with a focus on religion.

Further on, I took courses that reflected my interests in the conflict. A few significant courses taught by Harry Anastasiou titled Nationalism and Ethnic Conflict and another titled Perspectives in Conflict Resolution gifted many significant takeaways, providing a framework for analyzing the Israeli-Palestinian conflict.

Through my studies, it became clear that as a powerful identity reference, nationalism is a significant element driving the Israeli-Palestinian conflict. Moreover, within the broader narratives of nationalism on the respective sides, religious nationalism, which is the incorporation of religion into the nationalist narrative, also plays a key role, as it adds moral legitimacy to nationalism and its associated presumption of the supreme and sacred value of the nation-state. 
According to Juegensmeyer (1996), the role of religion in national politics has been on the rise since the 1990s. The role of religion in the Middle East has moved increasingly to the forefront of history since $9 / 11$ and significant questions have been raised regarding the role it plays in in promoting peace or conflict. Analysts of the three monotheistic religions of Judaism, Islam and Christianity, argue that these religions historically promoted both conflict and peace, which makes them ambivalent. Barash and Webel (2014) note that while all these religions reflect narrative and values of peace, they also have become party to much conflicts throughout history. Hatred based on ethnic and religious differences was at the root of many wars throughout history, including the Crusades in the Middle Ages, (European Christians versus Arab Muslims), and the Thirty Years' War (Largely Catholics versus Protestants), which devastated Europe in the 17th century (Barash \& Webel, 2014, p.175). Throughout the Middle East in particular, religion has become intertwined with the intensification of conflict and violence. This trend is also reflected in aspects of the Israeli-Palestinian conflict.

This thesis will focus on the two main groups in the Israeli-Palestinian conflict that have incorporated religion in their respective national identity and approach to the conflict, namely, the Jewish Orthodox and religious Zionists on the Israeli side and Hamas on the Palestinian side. The inquiry will also explore religious perspective on the two sides that have developed perspectives beyond the nationalist frameworks that have rendered the Israeli-Palestinian conflict protracted. 


\subsection{Problem Statement}

In light of the above, the inquiry of the thesis will explore the conditions under which religion becomes a catalyst for conflict, including lethal conflict and the conditions under which religion may become a catalyst for sustainable peace. 


\section{Chapter 2: Methodology}

The methodology followed in this thesis is qualitative content analysis, focusing on scholars, political figures, religious leaders, the press and charters. This thesis will begin with conflict analysis of the Israeli-Palestinian conflict to create a theoretical framework of the interethnic relations in this region, subsequently focusing on the religious dimension of the conflict. The qualitative methodology compares and contrasts the content of relevant texts as they bear on the research question. In this context, it is important to be sensitive to what this conflict means to the populations involved, particularly for the groups that carry a religious narrative.

The literature I chose to review derive from the religious ideology of Hamas and the religious perspective of Orthodox Jews and religious Zionists. This included the examination of Palestinian Sunni-Islam, their narrative, how their religious ideology connects to nationalism and on how they incorporate their fundamentalism into their approach to the conflict, including the use of violence. More specifically, the research will examine their view of Islam and how they incorporate their religion into their politics in the context of the Palestinian experience. I conducted research on the aforementioned dimensions of the Israeli-Palestinian conflict to allow readers to broaden their understanding when answering similar questions in their own studies, in an attempt to make sense of a foreign occupation and daily life within the Hamas controlled regions. In this light, I have included perspectives of the conflict through the lens of some of Hamas' most influential scholars and poets, including Mohamed Ikbal and al-Bukhari. I would also like to note the difficulties of paraphrasing that arose when examining the Hamas 
ideology. I felt that paraphrasing more could diminish Hamas's message to the reader. For this reason I presorted to several direct quotes.

Furthermore, including in the inquiry the works of critical scholars and poets is imperative as this would give a range of interpretations of Islamic tradition and its bearing on peace and violence. The research will subsequently focus on the Jewish Orthodox and religious Zionists and their religious ideology. This will include their narrative and how they incorporate religion into their politics and nationalism. 


\section{Chapter 3: Literature Review}

Understanding the role of religion in the Israeli-Palestinian conflict requires an understanding of the broader ethnocentric nationalist conflict between the two sides. The latter provides the context for researching the various ways in which adherents of the Jewish and Muslim religions respectively approach the function of their religion in the conflict. It must further be noted that while nationalism and its ethnocentric approach to statehood is a central driver in the history of the Israeli-Palestinian conflict, nationalism is not unique to either the Israeli or the Palestinian side, as nationalism is a master narrative that scholars associate with the historical development of modernity and the advent of nation-states (Alter, 1994; Anastasiou, 2008; Anderson, 1995; Gellner, 1983; Hobsbawm, 1990). For this reason it is necessary to review the literature on the basic characteristics of nationalism as a stepping stone to focusing on the Israeli-Palestinian conflict and function of religion within it.

The two-volume Encyclopedia of Identity, the most up-to-date compendium of scholarly work on the topic, profiles nationalism as one of the central references of identity. The Encyclopedia makes references to a broad range of identity references, from class, to race, to gender, etc. However, as a modernist narrative of identity formation, nationalism has a prominent role in conflict through its association with the nation-state. Be it in the secular or religious visions nationalism, is viewed by scholars as one of the most powerful forces in the modern world. So what are the key characteristics of this powerful narrative?

The notion of nationalism is ingrained in the everyday lives of citizens of modern nation-states. The pride people feel for national accomplishments, the articulations by 
politicians of the "national interests" in justifying policies, and the symbols that nations use for self-identification (e.g., flags, national anthems, and monuments) are prevalent references of nationalism as a collective identity, and help create a national consciousness among disparate individuals. While nationalism was essential to the structure of modern nation-states and can play and imperative role when societies face times of crises, it can also lead people and their leaders to view their nation as inerrant and beyond reproach, justifying the use of force and violence to deal with real perceived adversaries (Anastasiou and Broome, 2010).

Scholarly interest in the concept of nationalism amplified significantly during the 1980s and has continued to the present-day. Earlier studies focused on European nationalism as the driving force leading to the two world wars, but lately there has been more emphasis on non-western examples, specifically in Asia, Africa, and the Middle East. In the classical form of nationalism, which is implicated in the creation and conservation of sovereign states, loyalty to the nation takes precedence over all other loyalties, such as regional, local, or kinship ties. Contrary to classical nationalism, postnationalist states are more likely to raise individual rights, ingenuity, and diversity of communities within the nation as fundamental to democracy (Anastasiou and Broome, 2010).

In nationalism, the idea of the nation has a mastery over people that is perhaps best understood as an outgrowth of the exaggerated characteristics that the nationalist mind projects and bestows on the nation-state. Regardless of whether they see nationalism as a positive or negative force, scholars usually concede that in nationalism the nation is positioned on the highest pedestal, and viewed as the supreme agency of 
significance, collective identity, and moral justification. Eric Hobsbawn critically noted that one of the powerful ways in which nationalism becomes historically substantiated is through its presumption that the nation is sacred. Anthony Smith, a proponent of nationalism, similarly speaks of the nation as being a religion surrogate. This declaration can be applied both to nationalisms that have embodied traditional religion as part of their mental structure of values (e.g., Serbian, Greek, Hindu, Islamic, Irish Protestant and Irish Catholic nationalisms) as well as to secular nationalisms that aimed to abolish traditional religion from their values structures of national identity (e.g., Turkish, French, Egyptian, and Syrian nationalisms) (Anastasiou and Broome, 2010).

In regard to the nationalist approach to history, the attribution of sacredness to the idea of the nation has been ritualized in representations of national leaders, in ethnocentric public ceremonies, and in master narratives of national valiant acts that focus on extraordinary achievements, highlighted by revolutions and wars and stories of heroic acts. These nationalist narratives of history integrate selected historical facts into myths of national glory, greatness, binding destiny and greatness, and even divine election. Through an exaggerated notion of the nation, nationalist historiography protrudes a glorified image of the nation, placing it into a superlative, primal past, transformed by necessity into a convincing duty-bound present, and an infinite, grandiose future (Anastasiou and Broome, 2010).

In all these ways, nationalism develops a mono-centric, narcissistic concept of the nation's life-world, designing an image of a nation's history identifying the "good" with one's own nation and the "bad" with that of the "other," specifically of "the enemy other.” But according to Anastasiou and Broom (2010), 
The most problematic aspect of nationalism at both the national and international levels has been its capacity to link moral reasoning and the use of force/violence, especially in time of conflict. In a unique manner, nationalism has historically grounded the right to use force/violence in the moral rationale that the nation is the ultimate collective value and the imperative basis for community, identity, security and well-being. This configuration of belief and action has made nationalism a strong legitimizer of the use of force and violence throughout modern and much of post-modern history. The most prominent symbols of nationalism, ranging from national anthems, national flags, monuments and historiographies, disclose symbols and involve narratives of war, revolution, heroics, and the shedding of blood as supreme references of national identity, glory, and honor (Vol. II, p. 500).

Nationalism operates with the assumption that the structure of identity is exclusively and fundamentally mono-ethnic and one-dimensional. Ignatieff (1999), a renowned scholar of ethnocentric nationalism, explains that: "As a cultural ideal, nationalism is the claim that while men and women have many identities, it is the nation that provides them with their primary form of belonging" (p. 5). Ignatieff further notes that nationalism is the most powerful mobilizer and legitimizer of deadly violence and use of deadly force. He also asserts that unlike other references of identity and belonging, such as family or profession, nationalism provides a narrative that can readily resort to justifications for violence. He notes that it is not obvious "why national identity should be a more important element of personal identity than any other; nor is it obvious why 
defense of the nation justifies the use of violence" (p. 6). The implication is that unlike other aspects of identity, nationalism interprets national identity as supreme and sacred, and thus worthy of human sacrifice.

In looking at the wars and violence that have engulfed the Middle East in the post-9/11 era, as the broader context of the unfolding Israeli-Palestinian conflict, one observes the intensification of competing nationalisms within as well as between societies. The relapse of nationalism in the region and more specifically the rise of religious nationalism and militancy, have posed new challenges especially in confrontation with, and at times in alliance with militant transnational jihadism. When specifically talking about the Israel-Palestine conflict, identity conflicts revolve around the national identity configurations of the groups involved. Scholarly work by Rothman (2001) asserts the idea that identity-based conflicts contain primary elements that are based on mutual rejections of the legitimacy of the other side out of fear that such recognition will undermine one's own legitimacy, values, and claims. Rothman (2001) continues by saying that in the not so distant past, Israelis feared that If Palestinian claims were legitimate or taken seriously, they would undermine Israeli claims. Palestinians had the same fears about the Israelis. Thus, the situation and concession over resources and territory were viewed as zero-sum, primarily because of fears and mutual suspicion regarding identity recognition.

Auerbach (2011), adds that the Israel-Palestine conflict is also a conflict over real material assets, such as territory, water, border, security and the like. In connection to the Israeli-Palestinian conflict being a conflict over identity, Auerbach also adds that this conflict is one in which each side sees the national identity of the other side as a threat, 
or, as translating this identity into the political sphere-that is, into a "nation-state" -as a danger to its independent national identity. Auerbach continues by saying that the one side therefore rejects the definition if the other side as a nation or, at a minimum, denies its right to realize this identity in the context of national statehood. The Israeli-Palestinian conflict is, in essence, a conflict over identity because its origin and the cause of its continuation are rooted in each side's denial of the nationhood of the other side, and each side's claim to the right to establish its own ethnocentric nation-state (p. 100).

More specific to the present inquiry, the role and function of religion is contextualized within the abovementioned framework of Israeli-Palestinian nationalist conflict, so naturally religion of the two sides assumes a certain relationship to nationalism. One of the important scholars that addresses the relationship between religion and nationalism is Juergensmeyer (1996). In his work The Worldwide Rise of Religious Nationalism, focuses on the ascendancy of religious nationalism around the world and especially in the Middle East and in the Israeli-Palestinian conflict, a trend that scholars agree has intensified during the post-9/11 era. . Juergensmeyer indicates that there are two main kinds of religious nationalists: ethnic and ideological. Ethnic religious nationalists attack rival ethnicities, while ideological religious nationalists attack the secularity within their own country (government and supporters) or rival religions. He further states that, "If the ethnic approach to religious nationalism politicizes religion by employing religious identities for political ends, an ideological approach to religious nationalism does the opposite: it religionizes politics." This topic is essential as it notes the two basic ways in which religion becomes integrated into national politics, and national identity formations. 
In light of all of the above, we can now turn specifically to the role of religion in the Israeli-Palestinian conflict and its relationship to nationalism as a vital reference of identity. For the analysis that follows we will draw from several sources the most notable of which are the Covenant of the Islamic Resistance Movement, often referred to as the Hamas Charter, the Encyclopedia Judaica, and the Likud Party Platform, which presents the political position of the Likud party, which also incorporated elements of religious nationalism. The Hamas charter in its original version is in Arabic. However a number of scholars have translated the charter into many languages, including English. The Avalon Project of Yale Law School (1988) translated the Hamas charter into English, from which the subsequent analysis will draw in determining how religion functions in Hamas's approach to the Israeli-Palestinian conflict.

Moreover, in the analysis that follows we will also focus on authors and religious leaders from the two sides of the Israeli-Palestinian conflict, who approach religion as a framework of values that promotes peace across conflict lines. Rabbi Michael Learner, Jacques Derrida, Dr. Alon Goshen-Gottstein, Sheikh Imad Al-Falouji, Abdul Hadi Plazzi, are some of the relevant names that see religion as a catalyst for peace, to which we will turn in the latter part of our subsequent analysis. 


\section{Chapter 4: Analysis}

\subsection{Religious Migration and Rising Trends}

The religious ideologies in both Hamas and the Jewish Orthodox are a key element in how they view their politics in relation to the Israel-Palestine conflict. Though it has been frequently asserted that the Israeli-Palestinian conflict is about two peoples fighting over the same piece of land, it has also been considered as a religious and national geopolitical conflict. Before the establishment of Israel in 1948, in the 1920' and 30's Mohammad Amin al-Hussayni, the Grand Mufti of Jerusalem, attempted to prevent Jews from buying Arab land by persuading Arabs to donate their land to an Islamic holy trust, known as a waqf, an endowment made by a Muslim for a religious, educational, and charitable cause, where the land would be withdrawn from purchase by Jews. Without a known authority for its truth, Al-Hussayni spread word that Jews were going to take over the Temple Mount and Haram al Sharif and that stirred up animosity within the Arabs. This was one of the leading causes of the riots of 1929, where Jews were attacked in Hebron, Safed and Tel Aviv.

But religion played a relatively minor role before it toughened magnanimously after the 1967 war. It would be false to say religion was completely absent from the conflict because a small number of Jews moved to Palestine for religious reasons. However, religious morale strengthened greatly after 1967 due to Israel's military victories over its Arab enemies. Religious Jews began to believe that their victories were a sign from God that the Messiah was on His way. They believed their victory was a sign from above to redouble their efforts in settling all the land that was part of ancient Israel, from the Mediterranean to the Jordan. Numerous religious Jews known as right-wing 
religious-Zionists found their expression during the formation Gush Emunim- an Israeli, right-wing activist movement committed to establishing Jewish settlements in the West Bank, the Gaza Strip and the Golan Heights. Gush Emunim sprang out of the conquests of the 1967 Six-Day War, encouraging Jewish settlement of the land based on the belief that, according to the Torah, God gave it to the Jewish people" (Encyclopedia Judaica: Volume 8, p. 145). Gush Emunim no longer exists officially, but footprints of its influence remain in Israeli society.

The 1967 war sent shockwaves through the Arab world because the Arabs were defeated and the Palestinians were forced out of their homes, with no merit of return. Palestinians realized they could no longer rely on what was then the Arab League, and eventually turned to the Palestinian Leadership Organization (PLO), a secular nationalist organization established in 1964. Originally, the Palestinian people placed all their hopes on the PLO in their attempt to reclaim their land. But gradually they began to lose hope while Israeli settlers built more settlements in Gaza and the West Bank. The number of settlers grew rapidly over the years, from fewer than 1200 settlers in the West Bank in 1972 , to over 44,000 by 1985 . In the eyes of the Palestinian people, the PLO became ineffective and they gradually stated to seek stronger leadership. The Palestinians then set out in search of a new movement that addressed their need to regain what they viewed as their rightful homeland. They thus turned to political Islam.

In the form of religious nationalism political Islam exploded to the forefront of history with the Iranian revolution and the establishment of the Islamic Republic of Iran following the overthrow of the Shah in 1979. The establishment of the Islamic Republic of Iran grounded a Shi'a Muslim nationalism galvanized religious Muslims throughout 
the region, including an overwhelming number of Palestinians despite the fact that they were Sunni Muslims. Commenting of the impact of the Israeli invasion of Lebanon in 1982, Augustus Richard Norton wrote the following in his book, Hezbollah (p.33):

Even if Israel had not launched its invasion of southern Lebanon in 1982, the young would-be revolutionaries among the Shi'a would have pursued their path of emulating Iran's Islamic revolution. Undoubtedly, however, the invasion pushed the Shi'a further in this direction, creating conditions for the establishment and flourishing of Hezbollah.

The former Israeli prime minister Ehud Barack put the matter succinctly in July 2006: "When we entered Lebanon. . . there was no Hezbollah. We were accepted with perfumed rice and flowers by the Shi'a in the south. It was our presence there that created Hezbollah" (Newsweek, July 18, 2006). This statement strongly suggests that deadly conflict in the region contributed to the rise of militant religious nationalism among the Arabs.

Hezbollah (a Shiite group whose Arabic name translates to "The Party of God") was formed in Lebanon in 1982 and the mid 1980's. It was inspired by the prolonged Israeli invasion in 1982 and the rise of the Iranian Islamic Republic. Between the years of 1985 and 1986, the formation of Islamic Jihad and also Hamas took place. Founded in 1988, Hamas (which stands for the Arabic acronym "The Islamic Resistance Movement") was an offshoot of the Muslim Brotherhood, and grew as a result of the Iranian Revolution, but mostly in response to the oppressive Israeli occupation and Jewish settler violence in the West Bank. Hamas steadily grew and won the Palestinian elections in 2006. There are several factors that attributed to Hamas's victory: 
(1) The PLO was too weak and ineffective in alleviating the oppression of the Israeli occupation and failed to make any effort to stop the growth of settlements. By 2006, the number of settlers in the West Bank had grown over 260,000. Counter to the PLO, Hamas was seen as a force against the settlers and as having influenced the Israeli decision the pull out of Gaza in 2005.

(2) The Palestinian Authority created a negative reputation for itself due to corruption and cronyism and at the same time, as opposed to Hamas that developed a reputation of honesty and integrity.

(3) Hamas also built a foundation of benevolence amongst the Palestinian people by operating social programs such as mosques, school, soup kitchens and clinics.

By the time Hamas and right-wing religious Zionism were fully present on the Palestinian and Israeli sides respectively, the recourse to violence was seen by both sides as morally justified.

At present, the Jewish state of Israel, the West Bank and Gaza, are populated by leaders who believe that God endorses their national agenda, that God has given them all the land of the region, and that God wills that they secure the land and their statehood through all means including deadly force and violence. Such assumptions in the respective nationalist narratives made it easier to dehumanize the "other" and justify killings. 


\subsection{The Role of Religion on the Palestinian Side: Profile of Hamas's Ideology}

The Covenant of the Islamic Resistance Movement (CIRM) of 1988, often called the Hamas Charter, is one of the most demonstrative declarations that illustrate how Hamas incorporates religion into its politics. Researchers refer to Hamas's CIRM as defining its ideology. Starting with Article One of the CIRM, we observe that the movement's program is Islam. From the articles of the charter, it draws its ideas, its ways of judgment and interpretation of the universe, life and man. Hamas resorts to its charter for motivation and for admonition of its steps.

For Hamas's followers and believers, the CIRM is the foundation of how to live their everyday life and how to think of the world around them. In other words, the CIRM presents Hamas and its followers with a distinctive belief system, in contrast to belief systems outside of Islam. In addition, Article Six quotes the Muslim poet, Mohamed Ikbal, who declares that "If faith is lost, there is no security and there is no life for him who does not adhere to religion. He who accepts life without religion, has taken annihilation as his companion for life" (Avalon Project, 1988). According to Wheatcroft, Ikbal also believed that Islam is far from being a religion of private conscience and practice. Rather it is accompanied by a social order and legal concepts (2002).

As translated by The Avalon Project (1988) of the Yale Law School, the CIRM states that in pursuing the establishment of an independent Palestinian state, Hamas asserts that "Allah is its target, the Prophet is its model, the Qur'an its constitution". As will become evident in the following section, the CIRM contains quotes from the Quran, Islamic scholars and Islamic poets. In analyzing the CIRM, we will select the particular articles that articulate the role of religion in addressing a) territorial rights, b) 
interpretations in the use of deadly force and violence, and c) interpretation of the final political goal.

\subsubsection{The Role of Religion in Determining Territorial Rights}

In Article Eleven, the CIRM states that the land of Palestine is an Islamic Waqf, a type of sacred Islamic trust. As such, no part of this land can be sold or traded to anyone. It is land reserved for Muslims and negotiating it away would break trust with Allah. In its essence, the land, according to Hamas, is consecrated for future Muslim generations until Judgement Day. Article Eleven also insists that the land cannot be possessed, not even by Arabs. According to Article nine, Muslims are to fight, against the false, defeating it and vanquishing it so that justice could prevail, homelands be retrieved and from its mosques would the voice of the mu'azen (an announcer of daily prayers) emerge declaring the establishment of the state of Islam, so that people and things would return each to their right places and Allah is our helper. (Avalon, 1988)

In addition, Article Fourteen states that:

The question of the liberation of Palestine is bound to three circles: The Palestinian circle, the Arab circle and the Islamic circle. Each of these circles has its role in the struggle against Zionism. Each has its duties, and it is a horrible mistake and a sign of deep ignorance to overlook any of these circles. Palestine is an Islamic land which has the first of the two kiblahs (direction to which Muslims turn in praying), the third of the holy 
(Islamic) sanctuaries, and the point of departure for Mohamed's midnight journey to the seven heavens (i.e. Jerusalem). (Avalon, 1988)

As it is evident form the abovementioned quotes, Hamas believes that the Muslim religion bids them to the land of Palestine in a non-negotiable manner. Repossessing the land that was lost is equated with the will of Allah, who is believed to have granted the land as an inheritance to Muslims until the Day of Judgement.

\subsubsection{Religious Interpretations in the Use of Deadly Force and Violence}

The CIRM is premised on Muslims who have given their allegiance to Allah whom they truly worship. Article Three quotes Allah stating that, "I have created the jinn (an intelligent spirit of lower rank than the angels, able to appear in human and animal forms and to possess humans) and humans only for the purpose of worshipping". In this light, the primary responsibility of Muslims is to know the duty toward themselves, their family and their country, fear Allah and raise the banner of Jihad in the face of the oppressors, so that they would rid the land and the people of their uncleanliness, vileness and evils (Avalon, 1988).

Moreover, Article Seven includes a passage written by Islamic scholar, alBukhari. It states that:

The Day of Judgement will not come about until Muslims fight the Jews, when the Jew will hide behind stones and trees. The stones and trees will say Oh Muslims, Oh Abdulla, there is a Jew behind me, come and kill 
him. Only the Gharkad tree, would not do that because it is one of the trees of the Jews (Avalon Project, 1988).

Furthermore, the CIRM adheres to the fulfillment of Allah's promise, no matter how long that should take. Salvation will be delivered. According to Yahya (1994), Allah's promise to His believers is great bounties in both this life and the Hereafter, and people may hope to obtain them according to the degree of their faith and in closeness to Allah, as well as their submission and sincerity.

Additionally, Article Eight states the slogan of the CIRM, "Jihad is its path and death for the sake of Allah is the loftiest of its wishes". Furthermore, Article Thirteen states that initiatives, and so-called peaceful solutions and international conferences, are in contradiction to the principles of the CIRM. Abusing any part of Palestine is abuse directed against the Muslim religion. The nationalism of the CIRM is grounded in religion, and Hamas's members are raised on this narrative. For the sake of hoisting the banner of Allah over their homeland they fight (Avalon, 1988).

The CIRM also states that there is no solution for the Palestinian question except through Jihad. Initiatives, proposals and international conferences are all a waste of time and vain endeavors. The charter asserts that the Palestinian people know better than to consent to having their future, rights and fate toyed with. Article Thirteen also makes reference to an ally of the struggle, mainly Syria, it quotes from the Hadith, which states that:

The people of Syria are Allah's last in His land. He wreaks His vengeance through them against whomsoever He wishes among His slaves. It is unthinkable that those who are double-faced among them should prosper 
over the faithful. They will certainly die out of grief and desperation.

(Avalon, 1988)

Also, Article Fifteen states that on the day that enemies usurp part of Muslim land, Jihad becomes the individual duty of every Muslim. In face of the Jews' usurpation of Palestine, it is compulsory that the banner of Jihad be raised. To do this requires the diffusion of Islamic consciousness among the masses, both on the regional, Arab and Islamic levels. It is necessary to instill the spirit of Jihad in the heart of the nation so that they would confront the enemies and join the ranks of the fighters. Article Fifteen ends with a quote from Islamic scholar, al-Bukhari:

The bond of one day for the sake of Allah is better than the world and whatever there is on it. The place of one's whip in Paradise is far better than the world and whatever there is on it. A worshipper's going and coming in the service of Allah is better than the world and whatever there is on it. (Avalon, 1988)

Al-Bukari also stated that, "I swear by the holder of Mohammed's soul that I would like to invade and be killed for the sake of Allah, then invade and be killed, and then invade again and be killed".

Furthermore, in Article Seventeen, the CIRM states that:

Organizations such as information campaigns, films, and the school curriculum, using for that purpose their lackeys who are infiltrated through Zionist organizations under various names and shapes, such as Freemasons, Rotary Clubs, espionage groups and others, operate in the absence of Islam and its estrangement among its people. The Islamic 
peoples should perform their role in confronting the conspiracies of these saboteurs. The day Islam is in control of guiding the affairs of life, these organizations, hostile to humanity and Islam, will be obliterated. (Avalon, 1988)

In Article Thirty-Two, the CIRM states that, for "The Islamic Resistance Movement, leaving the circle of struggle with Zionism is high treason, and cursed be he who does that." What follows from this is a quote from the Quran, stating that, "For who shall turn his back unto them on that day, unless he turneth aside to fight, or retreated to another party of the faithful, shall draw on himself the indignation of Allah, and his abode shall be hell; an ill journey shall it be thither". The CIRM also asserts that there is no way out except by concentrating all powers and energies to face what they see as the vicious invasion of their land by the enemy. The alternative is loss of one's country, the dispersion of citizens, the spread of vice on earth, and the destruction of religious values. According to the CIRM, the fight for Palestine is a fight for humanity (Avalon, 1988).

\subsubsection{Religious Interpretation of the Final Political Goal}

Regarding the final end and vision of the national homeland, Article Twelve states that:

Nationalism, from the point of view of the CIRM, is part of the religious creed. Nothing in nationalism is more significant or deeper than in the case when an enemy should tread Muslim land. Resisting and quelling the enemy become the individual duty of every Muslim, male or female. A woman can go out to fight the enemy without her husband's permission, and so does the slave: without his master's permission. Nothing of the sort is to be found in any other regime. This is an undisputed fact. If other 
nationalist movements are connected with materialistic, human or regional causes, nationalism of the CIRM has all these elements as well as the more important elements that give it soul and life. It is connected to the source of spirit and the granter of life, hoisting in the sky of the homeland the heavenly banner that joins earth and heaven with a strong bond.

Article Twelve continues with a quote from the Quran saying:

Now is the right direction manifestly distinguished from deceit: whoever therefore shall deny Tagut (to cross the limits, overstep boundaries, or to rebel), and believe in Allah, he shall surely take hold with a strong handle, which shall not be broken; Allah is he who heareth and seeth. (Avalon, 1988)

Similarly, Article Twenty-Eight states that:

We (Muslims) should not forget to remind every Muslim that when the Jews conquered the Holy City in 1967, they stood on the threshold of the Aqsa Mosque and proclaimed that "Mohammed is dead, and his descendants are all women. Israel, Judaism and Jews challenge Islam and the Muslim people.

The CIRM ends the article with a quote, "May the cowards never sleep" (Avalon,1988). In Article Thirty-Four, the CIRM quotes the Quran anticipating a decisive final victory: "Say unto those who believe not, Ye shall be overcome, and thrown together into hell; an unhappy couch it shall be". The article further asserts: 
This is the only way to liberate Palestine. There is no doubt about the testimony of history. It is one of the laws of the universe and one of the rules of existence. Nothing can overcome iron except iron. Their false futile creed can only be defeated by the righteous Islamic creed. A creed could not be fought except by a creed, and in the last analysis, victory is for the just, for justice is certainly victorious. (Avalon Project, 1988).

In light of the above analysis it becomes evident how the Islamic Resistance Movement uses many passages of the Quran and the Hadith and morphs them into the movement's religious nationalist ideology as the foundation of what they perceive as the struggle for the liberation and establishment of the Palestinian state. It is also evident that Hamas's religious nationalism sees the establishment of a free Palestinian state and as an Islamic Palestinian state.

\subsection{The Role of Religion on the Israeli Side: Profile of Religious Zionist Ideology}

The Jewish Orthodox faction is considered to be the religious fundamentalist group on the Israeli side of the region. Within the Jewish Orthodox, there are what are called Zionists. Zionism does not have a uniform ideology, but has evolved through dialogue among a plethora of ideologies, one being religious Zionism. Before the establishment of the State of Israel, religious Zionists were mainly observant Jews (Jews who abide or adhere to the laws and duties of the Torah) who supported Zionist efforts to build a Jewish state in Palestine, or the Land of Israel. According to Rotberg (2007), these goals centered first on the establishment of a Jewish state in 1948 in the ancient homeland of Eretz Israel (Land of Israel). Historical, theological, national, existential, 
political, societal and cultural arguments were used to justify those goals. In analyzing these goals, we will select particular articles and literature that articulate the role of religion in addressing a) territorial rights, b) interpretations in the use of deadly force and violence, and c) interpretation of the final political goal.

\subsubsection{The Role of Religion in Determining Territorial Rights}

Israelis and Palestinians have had many issue that divide them. One of the most significant issues is territory, as this is central to the Israeli-Palestinian conflict. The issue of territories is so important that international bodies have addressed it. The international community considers Israeli settlements in the Israeli-occupied territories illegal under international law, because of the Fourth Geneva Convention (GCIV) of 1949 (a treaty that defines humanitarian protections and prohibits countries from moving population into territories occupied in a conflict). Along with the GCIV, many other international organizations, such as The United Nations Security Council, the United Nations General Assembly, the International Committee of the Red Cross, the International Court of Justice and the High Contracting Parties have affirmed that the GCIV does apply. And yet, in the eyes of religious nationalists, religious interpretations transcend international law.

Views from the religious Zionist perspective play an important part in approaching territorial rights in the region, especially by political Zionist figures. A case in point is Meir David Kahane, an American-Israeli Orthodox rabbi, ultra-Nationalist politician, teacher, and writer. His work became either the direct or indirect foundation of most modern Jewish militant and far right-wing political groups. Kahane was also an 
ordained Orthodox rabbi, who also served as a member of the Israeli Knesset. A significant part of Kahane's ideology was that, Israel should never start a war for territory, but if a war were launched against Israel, Biblical territory should be annexed. Kahane also defined Biblical territory as the southern boundary reaching El Arish (the largest city on the Sinai Peninsula), which takes in all of northern Sinai (Juergensmeyer, 1996).

To the east, the frontier runs along the western part of the East Bank of the Jordan River, hence part of what is now Jordan. Eretz Israel (land of Israel) also includes part of Lebanon and certain parts of Syria, and part of Iraq, all the way to the Tigris River. Kahane also stated that, "Miracles don't just happen". He felt that the only way for the Messiah to return is when the Jews create the right political conditions. Kahane, in fact said that, "Miracles are made" (Juergensmeyer, 1996).

Another case in point is the interview of Education Minister Naftali Bennett on Al Jazeera's UpFront. In the interview, Bennett cites the Bible as the basis of the Jewish claim to the occupied territories saying, "You need to change the narrative because it is all there". Bennett continued his statement by saying that there was never a Palestinian state, so you cannot occupy something that was never a state. Bennett also claimed that no Palestinian has ever been evicted from their home, except for those in "illegal buildings". "Give me the name of one Palestinian who was living in a home and had his home taken away from him," he said, before adding: "In Israel, if you build illegally, you take your home away". Bennett went on to say that Israel is doing a great job "hosting" its Palestinian population. "We host within our country millions of Arabs...that enjoy full 
citizenship. But it is a Jewish and democratic country," he said ("Israel's Education", 2017).

A look at the Likud Party (LP) the current governing party of Israel, also provides a perspective on the religious interpretation of territorial rights. The LP was founded in 1973 by secular Zionists embracing right-wing politics. But it is important to note that the party was also highly influenced by religious nationalists, partly because, they too, embrace right-wing politics. On the issue of territory, the Likud Party Platform (LPP) written in 1977 states the following:

The right of the Jewish people to the land of Israel is eternal and indisputable and is linked with the right to security and peace; therefore, Judea and Samaria will not be handed to any foreign administration; between the Sea and the Jordan there will only be Israeli sovereignty. (“Original Party", n.d.)

According to the religious Zionist perspective God entrusted the land (Biblical land) to the Jewish people and that there had never been a Palestinian state. Instead, Palestinians are viewed as living on land that is not theirs. The aspiration of religious nationalist is to achieve the establishment of "Greater Israel." Their religious interpretation requires the expansion of the current borders of Israel further and further.

During the 2016 U.S. presidential elections, Rabbi Yehuda Glick who is a member of the Knesset (Israel's Parliament), compared Trump to Cyrus the Great, the biblical king who issued an edict for the building of the Second Temple in Jerusalem. "I believe we're living in a biblical era". Glick explained. "I believe that if he became president, then God wants him to be president” (“In Donald Trump”, 2017). 
Glick continued to say that, "If God wanted him to be president, then we can only hope that he chooses to do the right things". Glick believes that with Trump in the White House, Israel will no longer be forced to agree to a two-state solution to the PalestinianIsraeli conflict, the position that U.S. administrations have championed since the beginning of the conflict. Religious nationalists such as Glick and many settlers want to drastically expand the Israeli settlements in East Jerusalem and the West Bank despite fierce opposition from the Palestinians and much of the international community. Eventually, they want to see Israel annex those areas (“In Donald Trump”, 2017).

\subsubsection{Religious Interpretations in the Use of Deadly Force and Violence}

The use of violence and lethal force in Israel and Palestine has grown as a consequence of repeated violent clashes and wars, of which the Gaza wars of 2008, 2012 and 2014 are the most recent cases. In this section of the analysis, the religious Zionist perspective on the use of force will be examined. The recourse to the use of deadly force by state of Israel is carried out by the Israeli Defense Forces (IDF), one of the most modern and powerful armies in the region. The IDF was originally build by the secular and democratic Israeli regime. Through the years, with the rising influence of religious nationalism, there was a process of religionization of the IDF. Questions among Israeli leaders and citizens were subsequently raised as to whether religion was a unifying or a divisive factor within the military. According to Israeli author, Ze'ev Drory (n.d.), at the beginning of the Zionist movement, the approach was to shelter under the wings of the IDF every Jew around the world, including religious Jews. It believed its duty was to let 
religious Jews identify with and feel part of that community, with the basic morals shared by all Jews.

However, in recent years, there has been a growing number of religious Jews who have joined the IDF, such that, the most significant change that the IDF has experienced is the functioning of religion within its institutional culture. Drory (n.d.) asserts that leaders of the national religious sector have inserted themselves into the military as key players. Their religious leadership has now superseded secular commanders, moving to higher and more powerful positions of rank. The louder their voices will become, the bigger the impact religion makes on the IDF. This is a strong implication that the IDF serves as an accomplice to religious influences in its use of force and violence in the Israel-Palestine conflict.

Comparatively, on February 1994, the day of the second Muslim Sabbath during Islam's holy month of Ramadan, Zionist settler, Baruch Goldstein, from the orthodox settlement of Qiryat Arba entered the crowded Ibrahim (Abraham's) Mosque, located in the biblical town of Hebron in the West Bank with the intention of killing Palestinians. He emptied three thirty-round magazines with his automatic Glilon assault rifle into the congregation of 800 Palestinian Muslim worshippers, killing 29 and wounding 150, before being beaten to death. This event was known as the "Cave of the Patriarchs Massacre". Goldstein was a longstanding follower of the abovementioned, radical Jewish fundamentalist group, and was motivated by a complex mixture of seemingly indivisible political and religious necessity, fueled by zealotry and a grave sense of betrayal. Goldstein stated that his prime minister (Rabin) was, "leading the Jewish state out of its God-given patrimony and into mortal danger” (Juergensmeyer, 1996). 
In the opinion of Swedish scholar, Ranstorp (1996), both the location and the timing of the Hebron massacre overlapped religious holidays of both Jewish Purim and Muslim Ramadan. A large segment of militant and orthodox Jewish settlers in West Bank and Gaza settlements portrayed Goldstein as a righteous man and hailed him as a martyr. During his funeral, these orthodox settlers also voiced religious fervor in uncompromising and militant terms, directed not only against the Arabs, but also against the Israeli government, which they believed had betrayed the Jewish people and the Jewish state. Ranstorp (1996) also claimed that:

Israeli leaders and the mainstream Jewish community tried to deny or ignore the danger of Jewish extremism by dismissing Goldstein as, at most, belonging to "the fringe of a fringe" within Israeli society. Any doubts of the mortal dangers of religious zealotry from within were abruptly silenced with one of the most outstanding events that discloses the religious nationalist events on the Israeli side- the assassination of prime minister Yitzhak Rabin.

The assassination of Rabin was a significant high point of religious nationalism. The rise of religious nationalism emerged from a common experience of disaffection over the dominance of modern Western culture, that seems to run parallel to Israeli secular nationalism. Rabin's assassination is a prime example. Rabin was assassinated by a young Jewish theological student, Yigal Amir, who claimed he had acted on orders of God. He declared: "Everything I did, I did it for the glory of God" (Juergensmeyer, 1996). Amir claimed he was at peace and that he felt normal. Amir argued that the murder of Rabin was commendable, according to certain readings of religious law. One 
of those laws, he claimed, allowed to defend against those who could destroy a nation. Amir had been influenced by militant rabbis and their halakhic (body of religious Jewish laws derived from the Torah) rulings, which he interpreted to mean that the "pursuer's decree" was to be applied against Israel's leader. Most Israelis may be astonished by the notion of a Jew killing another Jew, but Rabin was ultimately the victim of a broader force which has become one of the most vibrant, dangerous and pervasive trends in religiously motivated terrorism, as claimed by Ranstorp (1996).

\subsubsection{The Role of Religion in Interpreting the Final Political Goal}

The final goal of religious nationalists on the Israeli side is the establishment and sustenance of a Jewish state as a theocracy with extended borders. As previously mentioned, the LP consists of secular and religious Zionists, both of which embrace right-wing politics. The LPP includes a few clues of how they envision the boundaries of their Holy Land. For example, in a statement where the LPP is objecting to any plan that reduces the boundaries of their envisioned Holy Land, states the following:

A plan which relinquishes parts of western Eretz Israel, undermines our right to the country, unavoidably leads to the establishment of a "Palestinian State," jeopardizes the security of the Jewish population, endangers the existence of the State of Israel and frustrates any prospect of peace (“Original Party”, n.d., para. 1).

Focusing on settlements in the West Bank, the LPP also states that:

Settlement, both urban and rural in all parts of the Land of Israel is the focal point of the Zionist effort to redeem the country, to maintain vital 
security areas and serves as a reservoir of strength and inspiration for the renewal of the pioneering spirit. The Likud government will call on the younger generation in Israel and the dispersions to settle and help every group and individual in the task of inhabiting and cultivating the wasteland, while taking care not to dispossess anyone. ("Original Party”, n.d., para. 3)

Another significant element of the final political goal on the Israeli side is the expansion of settlements in the West Bank, Judea and Sumeria, and the removal of Palestinians from these areas. Former Israeli Housing Minister, Uri Ariel, expressed his Zionist plans for such a proliferation of settlements. Ariel is an Israeli orthodox Jew who is a current member of the Knesset. He also serves a spot in The Jewish Home, which is a radical right-wing Zionist political party in Israel. In an interview in The Middle East Monitor in 2014, Ariel declared the goal to "Eradicate remaining slivers of Palestinian territory". He continued to say that, "There will be just one state between the Jordan River and the sea, and that is the State of Israel". Ariel further asserted that there will be no more freezing of construction and no more delays, "Not in Jerusalem and not in Judea and Sumeria". Ariel declared the entire annexation of the West Bank as his way of conforming to early Zionist plans for the complete colonization of the region (Wadi, 2014).

Arial finished his statement by expressing that Palestinians will be granted Israeli citizenship after five years. But only after Palestinians complete a Hebrew language test and also sign a statement of loyalty to the Jewish State. If Palestinians complete all these tasks, he explained, they will be granted the right to vote, but not on a national level. 
In light of the above, the vision of religious nationalists on the Israeli side is the establishment of "Greater Israel" as a Jewish state that appropriates Palestinian territories.

\subsubsection{How Religious Nationalists Saw Donald Trump}

Religious nationalism on the Israeli side was also reflected in how certain Zionists responded to the 2016 election of Donald Trump as president of the United States. Religious nationalists saw the election of Donald Trump as an answerer many prayers. In their eyes, as well as in the eyes of secular right-wing nationalists, Trump's success in the U.S. elections gave a green light to build more settlements in the West Bank, in line with Israel's plan of achieving a "Greater Israel". As stated by the Times of Israel, the day after Donald Trump's victory in the American presidential election, the leader of the Israeli branch of the Republican Party, Marc Zell, visited the Western Wall in Jerusalem's Old City to thank God for Trump's win. Wearing suit and tie and a white "Make America Great Again" baseball cap, the co-chair of Republicans Overseas Israel danced with ultra-Orthodox worshipers and recited verses of thanksgiving from The Old Testament (“At Western Wall” 2016).

Zell also wrote a note, containing a wish, and placed it into the ancient stones of the wall and told reporters, "I came here simply because I wanted to express my feeling of gratitude to the Holy One, blessed be $\mathrm{He}$, for what $\mathrm{He}$ gave us, for what He gave Donald Trump and (American vice-president-elect) Mike Pence and the entire team, also in Israel and across the world." "I am in the clouds, really," Zell said, visibly moved at Trump's surprising victory. He also stated, "I believed it would happen, but when it 
actually came true, I didn't understand what's going on here. It's something supernatural" (“At Western Wall”, 2016).

Furthermore, an article from the Huffington Post states that, "Due to the presidential election of the new American President, Donald Trump, Israeli settlers see that as a message from God" ("In Donald Trump", 2017). For many settlers, "The election of President Trump was a kind of miracle," said retired Israeli Brigadier General Shlomo Brom, a former peace negotiator who now works at Israel's Institute for National Security Studies. Brom also stated that, "Everyone predicted that Clinton would be elected, so for them this is something that was done by God, which means that God supports them" (“In Donald Trump", 2017). 


\section{Chapter 5:}

\section{Comparative Contrast in the Functions of Religion on the Respective Sides}

The above analysis explicates the function of religion on the Palestinian side, as well as on the Israeli side. It is now in order to compare and contrast the approach of each side around the central themes that drove the aforementioned analysis, namely, the religious perspective on a) territorial rights, b) the use of deadly force and violence, and c) the final political goal. In light of the analysis presented in the previous sections, what is striking is that while the representatives of the religious perspective on each side see the other as the absolute enemy, they have very similar perspectives on the three themes mentioned above.

\subsection{Religious Perspective on Territorial Rights}

Both religious nationalisms claim more or less the same territory with the Israeli side claiming the land from the Mediterranean Sea to the Jordan River, and the Palestinian side claiming all the land that used to be Palestine prior to the establishment of Israel. Both sides adopt an exclusivist view of territory that in principle territory can never be shared with the other side or any other group. The two sides are also similar in their view that God gave them the land as an eternal inheritance that can neither be shared nor negotiated with anyone. The religious perspective on each side is also similar in that it is premised on the assumption that negotiating the land is tantamount to disobeying God and violating His will. 


\subsection{Religious Perspective on the Use of Deadly Force and Violence}

On the Israeli side, religious nationalists are willing to kill and be killed for the sake of sustaining their God-given patrimony, and on the Palestinian side, raising Jihad in the presence of the enemy is their religious duty. The religious nationalist perspective of each mirrors that of the other, in that religion, having been integrated into nationalism and national identity, legitimizes the use of force and violence. More specifically, each side views the conflict as one between good and evil, where God is on the side of one's own nation. By adding the religious dimension to the nationalist narrative, religious nationalists on each side intensify the hardline approaches to the Israeli-Palestinian conflict.

\subsection{Religious Perspective on the Final Political Goal}

On the Israeli side, maintaining and expanding the building settlements, is seen as aligned with God's creed. On the Palestinian side, their Islamic creed is seen as the sole basis for liberating and establishing a Palestinian state. The end goal of religious nationalists on the Israeli side is the establishment of "Greater Israel" that is distinctively and exclusively Jewish. The end goal of religious nationalists on the Palestinian side is the establishment of "Greater Palestine" that is distinctively and exclusively Muslim.

Based on the above comparisons, there is significant evidence that both the Israeli and Palestinian religious nationalists have fundamental similarities. Both denounce the other side completely, based on the presumption that their religiously prescribed nation is eternal and decreed by God. decree is eternal. For both sides, negotiating what they view 
as the land of their nation-state is tantamount to breaking trust with their God, and if that trust is broken, they will face the ultimate punishment. They both sides envision the establishment of their territorially expanded nation-state, where respectively the Israeli religious nationalists want a nation-state with an exclusive Jewish identity and the Palestinian religious nationalists want a state with an exclusive Muslim identity. The end goal of each side mirrors that of the other. As the two sides make maximalist claims on the same territory, with concepts of nationhood that have exclusive religious identities, establishing a Greater Jewish state and a Greater Muslim state, entail contradictory and mutually exclusive end goals.

In identifying the above similarities, in the religious nationalism of each side, one can see how the respective perspectives cannot possibly contribute to a negotiated peace. They exclude each other in such an absolute way, that they end up being fundamentally irreconcilable, which practically means, they cannot, by their very nature, negotiate peace. Rather, they remain entrenched in conflict. 


\section{Chapter 6: Alternative Approaches to the Role of Religion- Peace}

Throughout this thesis, we have focused on the rise of religious nationalism and how the role of religion functions as a catalyst to conflict. As previously mentioned, Judaism and Islam as the two of the main monotheistic religions in the Israel-Palestine region, argue that historically these religions also promote peace. The remainder of this thesis will examine Israeli and Palestinian pro-peace leaders, and how differently they approach religion in the context of the Israeli-Palestinian conflict compared to religious nationalists.

\subsection{On the Israeli Side}

One of the most notable pro-peace leaders on the Israeli side is Dr. Alon GoshenGottstein, the director of the Elijah Institute in Jerusalem. His mission, is to create understanding and harmony between the world's religions. His institute does this through interfaith dialogue, education, research and dissemination between the world's diverse faith communities. The Elijah Institute's unique programming generates interfaith dialogue at the highest levels, bringing together religious leaders and renowned scholars from around the globe, through research projects, public conferences, community-based initiatives, and prayer.

Dr. Goshen-Gottstein has a vision of a center called the House of Vision and Hope (H.O.P.E.), that he claims is inspired by the prophecy of God's house being a house of prayer for all people. He expresses his vision by noting that:

There is not a single institution in all of Jerusalem in which its religions share and come together. There is no interreligious center anywhere in the 
Holy Land that is frequented by members of the three religions and there is absolutely no sense of the possibility of sharing a site or a place of worship, as a means of seeking to express and deepen the quest for peace and harmony between Jerusalem's religions. In fact, there is no such center anywhere in the world. Once such a center is created, it would provide a powerful symbol of the potential that Jerusalem has to be a city of peace, rather than one of tension ("Elijah Interfaith, n.d.).

In addition to Jewish leaders in the region, there are Jewish leaders among the American Jewish community who articulate a pro-peace approach to religion. One of most prominent is Rabbis Michael Lerner (2014), a pro-peace activist, and one who lives in the United States, but makes frequent visits to Israel. He asserts that today religious traditions and different versions of Judaism entail models and archetypes for the significance of peace, but criticizes that religious nationalist approaches are not aligned with Judaism. He is critical and disapproves of religions when they vilify the other. In contrast to the latter approach, his alternative approach to religion is one that prioritizes the promotion of peace and the positive change peace movements aspire to achieve.

But Lerner also has some criticism of peace movements. He notes that peace movements are often known as focusing on what they are against. From his religious perspective, Lerner asks the question as to why people, who are involved in peace studies and peace movements, do not give greater political support to social movements and political movements that unequivocally support peace. He continues to say that part of the answer has to do with the failures of peace movements and peace and conflict studies, 
focusing on what they are against. Instead, he asserts, peace movements need to promote peace and educate others to promote a vision of a world based on peace.

Lerner (2014) also promotes the concept of Jewish Renewal, a small Jewish movement which he describes as "positive Judaism", rejecting what he considers to be ethnocentric interpretations of the Torah. His publications promote religious pluralism and progressive or liberal approaches to political problems. Lerner is also a critic of what he calls the "Israel can-do-no-wrong voices in American politics". He explained that this mentality, which frequently leads to accusations that Jews who oppose Israel's policies toward the Palestinians are "self-hating Jews", alienates young Jews who "say that they can no longer identify with their Jewishness" (Lerner, 2007).

At an interfaith gathering in Spain, Jewish, Muslim and Christian clergy came together to denounce violence and vow to promote a life of mutual respect. Organizers of the gathering said in a statement that while some participants were "considered extremists," the clergy recognized the "special responsibility to contribute to the desired peace". For example, current Ashkenazi Chief Rabbi of Israel, David Lau (2016) was recently quoted at the gathering saying that:

The violence that is conducted, supposedly in the name of God, is a desecration of His name, a crime against those who are created in His image, and a debasement of faith. The proper means of solving conflict and disagreement is by negotiation and deliberation only (Staff, 2016). 


\subsection{On the Palestinian Side}

Religious pro-peace leaders on the Palestinian side have also been forthcoming in recent years expressing their views on the Israel-Palestine conflict. An example of this would be Hamas-linked Sheikh Imad Al-Falouji, one of the founders of an armed wing of Hamas who now serves as the chairman of the Adam Center for Dialogue of Civilizations in Gaza. Having moved beyond his militant past, he stated that, "We vehemently call for the cessation of incitement, misrepresentation and distortion of the image of the other and of the neighbor". Al-Falouji and Rabbi Lau were both seen at the same interfaith summit in Spain, declaring and advocating a non-violent solution to the conflict. Both expressed their recognition of the "right of the two peoples to exist with dignity", and urged Israeli and Palestinian leaders to come together and work towards that goal, also stating that, "We commit ourselves to educate future generations to uphold mutual respect" (Staff, 2016).

Another religious pro-peace leader is Abdul Hadi Palazzi. He is the Secretary General of the Italian Muslim Assembly but also a co-founder of the Islam-Israel Fellowship. The fellowship promotes a positive Muslim attitude towards Jews and Israel based on what Palazzi believes are the authentic teachings of Muhammad as expressed in the Qur'an and the Hadith. He accepts Israel's sovereignty over Jerusalem, if the rights of other religions are protected. He quotes the Qur'an to support Judaism's special connection to the Temple Mount. According to Palazzi (2001), Jerusalem is also sacred to Muslims because of its prior holiness to Jews and its standing as home to the biblical prophets and kings David and Solomon, all of whom, he says, are sacred figures also in Islam. He claims that the Qur'an "expressly recognizes that Jerusalem plays the same role 
for Jews that Mecca has for Muslims." When asked what the Qur'an says about the State of Israel, Palazzi replied:

The Qur'an cannot deal with the State of Israel as we know it today, since that State came into existence in 1948 only, i.e., many centuries after the Qur'an itself was revealed. However, the Qur'an specifies that the Land of Israel is the homeland of the Jewish people, that God Himself gave that Land to them as heritage and ordered them to live therein. It also announces that — before the end of the time - the Jewish people will come from many different countries to retake possession of that heritage of theirs. Whoever denies this actually denies the Qur'an itself. If he is not a scholar, and in good faith believes what other people say about this issue, he is an ignorant Muslim. If, on the contrary, he is informed about what the Qur'an says and openly opposes it, he ceases to be a Muslim (2010).

Another religious pro-peace leader who asserts that the return of the Jews to the Holy Land, and the establishment of Israel, are in accordance with teachings of Islam, is Sheikh Muhammad al-Hussaini. Al- Hussaini is a British Muslim scholar who understands the texts of the Qur'an and asserts that Muslims can be convinced of his interpretation. He claims that until now there has been no respectable dialogue regarding these founding texts but dialogue is possible. He continues saying that:

First, by recognizing that the Qur'an does, in fact, confirm the Biblical promise, then by re-reading commentaries on the Qur'anic text where the Jewish claim is strengthened. Beyond that, although the Jews come in for severe criticism in the works of Muslim apologists and 
theologians, there are no grounds in religious law to entertain the conceit that God's promise to the Children of Israel has been broken, and none to support the view that Israel is now the property of the Muslims. This effort involves an approach to the analysis of texts that requires Muslim scholars to take lessons from modern Biblical interpretation as practiced by Christian and Jewish interpreters of scripture working singly and together (2009).

\subsection{How do they Define Religion Differently}

Pro-peace religious leaders previously mentioned that address the IsraelPalestine conflict view their religion in a way that counters that of religious nationalists in significant ways. Pro-peace leaders hold themselves and the view of their nation at a value no less than any other religion or nation. Moreover, they view the right to exist and the value of human life as higher than anything else. These leaders define their religion as contributing to peace, negotiation and deliberation, to exist with dignity, and mutual respect. Most importantly, they view violence against one's fellow man as a violation of God's creed, and they view war as the ultimate sin. In addition, these religious voices that are among these pro-peace Jews and Muslims also identify with what has been called the Abrahamic religions.

\subsection{Abrahamic Religions}

It is important to note that these pro-peace monotheistic religions of Islam, Judaism and Christianity in the Israel-Palestine region are also referred to as the 
Abrahamic religions and as Abrahamism. They represent a group of Semiticoriginated sects that claim descent from the practices of the ancient Hebrews. They view themselves as descendants of the worship of the God of Abraham. The major Abrahamic religions in chronological order of founding are:

- Judaism (seventh century BCE)

- Christianity (first century CE)

- Islam (seventh century CE)

According to the history of Abrahamic religions, Judaism began as a local tribal cult, and then the Abrahamists were able to spread globally through Christianity being adopted by the Roman Empire in the 4th century and through the military campaigns of the Arabs who spread Islam from the 7th century onward. As a consequence, today the Abrahamic religions are one of the major categories in comparative religion (along with Indian, Iranian, and East Asian religions). Judaism, Christianity, and Islam are the largest Abrahamic religions in terms of numbers of adherents (Derrida, 2002).

The Abrahamic religions, have common roots in Abraham, who is an essential figure in the Bible, the Torah and the Qur'an. This conclusion also validates the previously mentioned Sheikh Muhammad Al-Hussaini, his claim that, Jewish claims to their Holy Land rest in passages of the Torah and the Qur'an, meaning that Judaism and Islam come from one spiritual source. This means that if Judaism and Islam derive from a single source, then they derive from a similar ancestry. Thus, since they derive from the same ancestry, then they affirm one eternal God who created the universe, whose grace is bestowed equally on all people. 


\section{Chapter 7:}

\section{Concluding Remarks and the Way Forward: Recommended Directives for Conflict Resolution}

In light of the above analysis, we can now revert back to the problem statement that drove the research of the present thesis, in order to summarize and conclude on our findings. Given the ambiguous role that religion has played in peace and conflict phenomena, our inquiry attempted to explore the conditions under which religion becomes a catalyst for conflict, including lethal conflict, and the conditions under which religion may become a catalyst for sustainable peace. The inquiry was pursued in the context of the Israeli-Palestinian conflict by examining the various narratives informed by religion and how they function in relation to the conflict.

What transpired from the analysis was that on both the Israeli and the Palestinian sides one finds two contrasting approached to religion in relation to the conflict. On the one hand, Hamas among the Palestinians and religious Zionists and Orthodox Jews among the Israelis reflect narratives of religious nationalism, characterized by an absolutist and adversarial approach to the other, in ways that lead to deadlock and impasse, as well as to intensification and hardening of the conflict. On the other hand, particular religious leaders among Israeli Jews and religious leaders among Palestinian Muslims reflect what may be called post-nationalist approaches to religion, characterized by prioritizing peace, reconciliation and mutually respectful coexistence between Israelis and Palestinians.

To summarize: Israeli and Palestinian religious nationalists accept the absolutism of their nation-state and the exclusivity of its ethnic and religious identity. Israeli and 
Palestinian religious post-nationalists reject the absolutist view of the nation-state and the exclusivity of the nation's ethnic and religious identity, opting instead for a more open and flexible approach to the nation-state on the basis of accepting the equality and diversity of identities. Religious nationalists among Israelis and Palestinians approach the issue of the land in a maximalist and exclusive way, claiming that God gave them the land as an eternal inheritance- - a position that makes it impossible to address the issue of territory in the Israeli-Palestinian conflict.

In contrast, religious post-nationalists reject this approach as antithetical to their creed. Instead they support negotiations and diplomacy in a spirit of reconciliation as the way to address territorial rights. Whereas both Israeli and Palestinian religious nationalists view the conflict as one of good versus evil, with God on their side, religious post-nationalists view the conflict as destructive and evil and God on the side of peace. Religious nationalists view war and violence as a religiously and morally legitimate means of pursing national objectives, whereas religious post-nationalists reject war and violence, as they view war and violence to be contrary to their religious creed. Religious post-nationalists believe that peaceful means of addressing the Israeli-Palestinian conflict, such as dialogue, negotiations and diplomacy, are more aligned with their religious creed and constitute the pathway to peace and security.

Following the examination of the various narratives that have a bearing of the role of religion in the Israeli-Palestinian conflict, the above summary, crystalizes the approaches to religion that differentiate the conditions under which religion functions as a catalyst for conflict from the conditions under which religion functions as a catalyst for peace in the context of the Israeli-Palestinian conflict. The question that naturally follows 
from this conclusion is, what is the recommended way forward in regard to the function of religion in the Israeli-Palestinian conflict?

The landscape of how religion functions in the Israeli-Palestinian conflict disclosed contradictory approaches in regard to the national issues and goals as viewed by each side. In light of the findings, certain directives can be recommended that may constructively assist and support conflict resolution and peacebuilding processes.

The first directive is to pursue an increase in engagement between religious nationalists and pro-peace, religious post-nationalist within Judaism. The same is recommended among Muslims in the Palestinian community. The first recommendation is therefore the initiation and intensification of intra-religious dialogue within the Israeli community and the Palestinian community respectively. Building on the first recommendation, the second directive is to pursue engagement in inter-religious dialogue between Israeli Jews and Palestinian Muslims in the context of the Israeli-Palestinian conflict.

Numerous scholars have also given support for the abovementioned directives. For example, Scholar Susan Hayward (2010) suggests that it can beneficial to conduct separate intra-religious preparatory sessions with each religious community prior to the inter-religious dialogue. Hayward continues by saying that having dialogue within their religion, allows participants from each group to explore the topic that would be discussed, in order to familiarize themselves with it, to establish points of agreement and disagreement inside their own group, and further, to explore concerns or hopes regarding the interfaith encounter (p. 28). 
In conflicts such as the Israeli-Palestinian conflict, these intra-religious encounters, can be just as important, if not more important, as inter-religious encounters. Scholar Marc Gopin (2010) was a participant in conflict resolution processes in the Israel-Palestine region that included religious leaders from all sides of the conflict. He claims that in the face of extraordinary suffering and insecurity, many individuals use their beliefs, values, stories and sentiment to understand their situation. He argues that a peaceful religion is one that sustains a solid sense of identity alongside and with respect for other traditions. As such, the element of peacebuilding through religion, should entail finding the resources within each religion to promote this form of identity, as opposed to an exclusivist and violent religious identity. Peace-makers should then consider immersing themselves in the traditions and world views of those in conflict, in order to explore how to engage and encourage more positive interpretations (p.25).

Religious leaders, with their teachings, values and institutions can work as community members on interpreting their political and social realities in part or in whole through a religious lens, to promote social behavior and attitudes as a way of speaking in their own interpretive language to their community members. This is where interfaith dialogue can be used for peace and justice-making. As a result of this work, especially in times when political, social or economic tensions arise, these kinds of dialogue allow for conflicts to be addressed, along with misunderstanding being corrected and solutions negotiated, even before large-scale violence breaks out (Hayward, 2010).

For example, in 2009, former Norwegian Prime Minister Kjell Bondevik spoke at a meeting of the Common Word Initiative, a global Muslim-Christian dialogue project. At this meeting, Bendevik recounted how the cartoons published in Denmark in 2005 
caused outrage among Muslim communities. The cartoons were similarly published in Norway. In Norway, however, there had been sustained interfaith dialogue in the years preceding. Bondevik reflected that, when the cartoons were published, Christian, Muslim and other religious and political leaders instantaneously came together, and reacted to the emerging crisis in unison. Bondevik argued that this may have been part of the reason why in Norway, the controversy did not erupt to the crisis level that it did in Denmark. He finished by saying that since in Denmark there was less history of interfaith dialogue, there were fewer avenues for resolution, and less trust between, leaders from the communities to address the crisis promptly before it escalated (Hayward, 2010).

All of the world's religions have sought to introduce practices and values that can reduce negative social and political dynamics, much like the conflict in Israel and Palestine. One of the essential practices that is affirmed in the teachings of many religions, is compassionate engagement with those of other communities. Interfaith dialogue on its own cannot end conflict and create justice around the world. However, it is a powerful tool for relationship building to amplify sustainable activism and sustainable relationships across the ethno-religious divides, including the Israeli-Palestine divide. 


\section{References}

A. (2017, February 23). Israel's education minister on Al Jazeera cites the Bible as the Jewish claim to the Occupied Territories. Retrieved April 05, 2017, from http://pr.aljazeera.com/post/157603426520/israels-education-minister-on-al-jazeera-cites

Ahren, R., Agencies and Times of Israel staff, Pileggi, T., Hussein, S., Winer, S., Zion, I. B., . . Magid, J. (2016, November 09). At Western Wall, head of Israeli GOP thanks God for Trump win. Retrieved from http:/www.timesofisrael.com/at-western-wall-headof-israeli-gop-thanks-god-for-trump-win/

Alter, P. (1994). Nationalism (2nd ed.). London: Hodder Arnold.

Anastasiou, H. (2008). "Encountering Nationalism: The Contribution of Peace Studies and Conflict Resolution." In Dennis J. D. Sandole, Sean Byrne, Ingrid Sandole-Staroste, Jessica Senehi (Eds.) Handbook of Conflict Analysis and Resolution. New York:

Routledge.

Anastasiou, H. (2009). Encountering Nationalism: The Contribution of Peace Studies and Conflict Resolution. In Handbook of Conflict Analysis and Resolution (pp. 32-44). Routledge. doi:https://doi.org/10.4324/9780203893166.ch2

Anastasiou, H. (with Broome, B. J.) (2010). "Nationalism.” In Ronald L. Jackson II (Ed.) Encyclopedia of Identity. Volumes I \& II. Sage.

Anastasiou, H. (2014). Eastern Orthodox Christianity. In Peace on Earth (pp. 243-262). Langham, MD, Lexington.

Anderson, B. (1995). Imagined Communities. Reflections on the Origin and Spread of Nationalism. London: Verso.

Auerbach, Y. (2010). National narratives in a conflict of identity. Barriers to peace in the Israeli-Palestinian conflict, 99-134.

Berman, S.J. (2001, February 1). The Ideology of Modern Orthodoxy | Sh'ma Journal. Retrieved January, 2016, from http://shma.com/2001/02/theideology-of-modern-orthodoxy/

Derrida, Jacques (2002). Anidjar, Gil, ed. Acts of Religion. New York \& London: Routledge.ISBN 978-0-415-92401-6. 
Drory, Z. (n.d.). The 'Religionizing' of the Israel Defense Force: Its Impact on Military Culture and Professionalism. Retrieved from http://resmilitaris.net/ressources/10195/70/res_militaris_article_drory_the_religionizing of_the_idf.pdf

Elijah Interfaith - Sharing Wisdom Fostering Peace. (n.d.). Retrieved May 20, 2017, from http://elijah-interfaith.org/

Encyclopedia Judaica: Volume 8, p. 145

Norton, A. R. (2014). Hezbollah: a short history. Princeton: Princeton University Press.

Gellner, E. (1983). Nations and Nationalism. Ithaca, NY: Cornell University Press.

Gopin, Marc. "Engaging across Divides: Interfaith Dialogue for Peace and Justice." (2010): 21-29. State of the World's Minorities. Web.

$<$ http://minorityrights.org/wp-content/uploads/old-site-downloads/download 843-Engaging-across-divides-interfaith-dialogue-for-peace-and-justice.pdf $>$.

Hamas Covenant 1988. (2008). Retrieved from

http://avalon.law.yale.edu/20th_century/hamas.asp

Hayward, Susan. "Engaging across Divides: Interfaith Dialogue for Peace and Justice." (2010): 21-29. State of the World's Minorities. Web. <http://minorityrights.org/wpcontent/uploads/old-site-downloads/download-843-Engaging-across-divides-interfaithdialogue-for-peace-and-justice.pdf $>$.

Hobsbawm, E. (1990). Nations and Nationalism since 1780: Program, Myth, Reality. Cambridge: Cambridge University Press.

John Stoessinger. 1962. The Might of Nations. New York: Random House.

Juergensmeyer, M. (1996). The worldwide rise of religious nationalism. Journal of International Affairs, 1-20.

Lerner, M. (2007, February 07). There Is No New Anti-Semitism. Retrieved May 14, 2017, from http://baltimorechronicle.com/2007/020207LERNER.shtml 
Lerner, Michael (2014). Judaism and the Path to Peace. In Peace on Earth (pp. 105-120). Langham, MD, Lexington.

Mkwords.com. (n.d.). Retrieved from http://mkwords.com/text/?i=86\&a=Palestine

'Mothers of all Palestinians should also be killed,' says Israeli politician. (2015, May 12). Retrieved from https://www.dailysabah.com/mideast/2014/07/14/mothers-of-allpalestinians-should-also-be-killed-says-israeli-politician

"Muhammad Al-Hussaini. The Qur'an's Covenant with the Jewish People". Middle East Quarterly. Fall 2009, pp. 9-14. 2009-03-19. Retrieved 2010-04-13.

Original Party. (n.d.). In Jewish Virtual Library. Retrieved from http://www.jewishvirtuallibrary.org/original-party-platform-of-the-likud-party

Palazzi, Imam. (2010). Dollars for Terror: The United States and Islam. Algora Publishing. "Land of Israel is the homeland of the Jewish people-Imam Palazzi". Weekly Blitz. Volume \#5, Issue \#42, October 13, 2010

Ranstorp, M. (1996). Terrorism in the Name of Religion. Journal of International Affairs, 41-62.

Rotberg, R. I. (2007). Israeli and Palestinian narratives of conflict: history's double helix. Bloomington, IN: Indiana Univ. Press.

Rothman, J. (1997). Resolving Identity-Based Conflict In Nations, Organizations, and Communities. San Francisco, CA: Jossey-Bass Inc. Publishers.

Schwartz, Y. (2017, March 29). In Donald Trump, Israeli Settlers See A Message From God. Retrieved from http://www.huffingtonpost.com/entry/donald-trump-israelsettlers_us_58d94a66e4b03787d35aceec

Shimoni, G. (1995). The Zionist Ideology (Vol. 21). Brandeis University Press.

Staff, T. O. (2016, November 19). Hamas-linked imam, Israel chief rabbi unite in call for peace. Retrieved May 15, 2017, from http://www.timesofisrael.com/hamas-linked-imamisrael-chief-rabbi-unite-in-call-for-peace/

Wadi, R. (2014, May 30). Israeli Housing Minister Uri Ariel advocates for the complete colonisation of Palestine. Retrieved May 13, 2017, from 
https://www.middleeastmonitor.com/20140530-israeli-housing-minister-uri-arieladvocates-for-the-complete-colonisation-of-palestine/ What is Hamas? (2012, November 20). Retrieved February 01, 2017, from https://palestineisraelconflict.wordpress.com/what-is-hamas/

Yahya, H. (1994). Allahs beautiful promises to believers necessitate that they remain hopeful. Retrieved April 02, 2017, from http://www.harunyahya.com/en/DailyComments/12690/allahs-beautiful-promises-to-believers 